6. Shmeleva E. S. Models of puns. Bulletin of Moscow state linguistic university. 2017. Vol. 10 (783). P. 77-87

7. Statista. Most popular social networks worldwide as of October 2020, ranked by number of active users. Retrieved from https://www.statista.com/ statistics/272014/global-social-networks-ranked-by-number-of-users/

DOI https://doi.org/10.30525/978-9934-26-073-5-1-52

\title{
VERBAL REALISATION OF HUMOR AND ITS FEATURES IN THE GERMAN-SPEAKING STAND-UP COMEDY GENRE
}

\author{
Zhuhai V. V. \\ First year postgraduate student \\ Institute of Philology \\ Taras Shevchenko National University of Kyiv \\ Kyiv, Ukraine
}

The following research aims to debunk some of the existing myths about the lack of humour in the German-speaking cultural space using the material of the German-speaking comedy in the sphere of stand-up while also developing a theoretical basis for the humor's analysis with the help of contextual, linguistic, and pragmatic analysis.

The phenomena of humor and laughter have puzzled representatives of philosophical, psychological, and linguistic thought for centuries, starting with Plato, followed up with the early Christians and great thinkers, like R. Descartes, I. Kant, A. Schopenhauer, psychologists like Freud, even the author of the evolution theory, C. Darwin. [6, p. 4-8] Laughter has been thought to be a hostility reflex by some [6, p. 4] and called the ultimate relief instrument by others $[6, \mathrm{p} .5]$, while the more modern scholars would call it a result of one's expectations being violated $[6$, p. 8]. Throughout our research, we established that there is some confusion regarding what humor and laughter are. According to some sources [5, p. 2], laughter is the luxury reflex, summoning the coordination motion of 15 facial nerves, however serving no obvious biological purpose other than stress relief.

As a comedic genre, stand-up comedy has existed for at least a hundred fifty plus years, thought to have originated in the 1840s in Great Britain. [1] However, stand-up comedy in its modern variation started to take form a couple of decades later with Mark Twain's humoristic performances in the United States [1]. The genre evolved relatively slowly until the introduction of 
radio and television to the mainstream, which forced the comedians to produce more material and publish it more frequently. Political and social humor was introduced by the comedians in the post-Second World War period [1]. These events coincided with the creation of the first comedy shows.

In parallel, the comedy scene did not appear in Germany until the $1990 \mathrm{~s}$, when the German-speaking audience first saw the performances of artists like Otto Waalkes [9].

The present-day (the modern) stand-up comedy is a popular and rapidly growing comedy genre, manifesting itself in talk shows, reality shows, and content published on social media, like YouTube, Instagram or TikTok. Germany and other German-speaking countries are no exception. The modern social media tools allow users coming from within the country and outside to determine the popularity of certain individuals, channels, or media outlets. Therefore, the humor published on social media, preferably YouTube, but also Instagram and other platforms, will serve as the object of this research.

In our research, we decided to investigate a collection of performances of various German comedians to form a certain corpus of micro-contexts, best suitable for detailed linguistic and pragmatical analysis. The search pool included a list of over 50 German-speaking comedians from Germany and other countries sharing the same cultural space. For the best possible scientific results, it was assumed that: 1 . The comedians / artists performed using the German language; 2. The comedians / artists established themselves on the social media and have an active audience; 3 . Analyzed were parts of the most recent performances throughout the span of 2015 - present.

The list with the comedians' names was formed after researching the German-language Internet portals, press releases and online media outlets in the years 2015 to present. That covered some of the more well-known publications like Zeit [8] and Spiegel [3], but also lesser-known ones, like Kratsch-Tratsch [4]. Included were the names of comedians, deemed 'popular' or mentioned as winners in various nominations during a limited timeframe. The list was later narrowed down to fifteen by applying the popularity filter the comedians to make the list have a total audience of a 1 million viewers or followers, and more across the different social media (Facebook, YouTube, Instagram). This step was necessary to carry out an unbiased analysis of who the most popular comedians in the German-speaking cultural space were.

The theory of scripts developed by Victor Raskin [7, p. 325-335] and the General verbal Theory of Humor by V. Raskin and S. Attardo [2, p. 27] constitute a theoretical foundation for the analysis of the proposed microcontexts. Other research methods included: the contextual and linguistic 
analysis (on the phonetic, morphological, lexical, syntaxial and stylistic levels).

The following research was intended to lay a theoretical foundation for humor analysis as well as to determine and analyse the functional elements in humor, that contribute to its effect, i.e., making the individual smile or laugh. It has been well established that humor sense can vary from one individual to another. The study results show, that while effective, German humor requires from the recipient a certain level of not only linguistical, but also cultural, political, and social competence for it to be considered 'funny' or 'comical'.

\section{References:}

1. Висміяти реальність: зародження стенд-апу в Україні та США. Пространство. 2021. URL: https://bit.ly/3sAnHAm.[In Ukrainian].

2. Attardo S. Humorous texts: a semantic and pragmatic analysis. BerlinNew York: Mouton de Gruyter, 2001. 238 p. [In English].

3. Deutsche Comedypreis: Luke Mockridge als „bester Komiker» geehrt. Spiegel.URL: https://bit.ly/2Qi76nM [In German].

4. Die besten deutscher Komiker aller Zeiten gewählt: Oliver Pocher ist auch dabei. Klatsch-Tratsch. 2015. URL: https://bit.ly/3szBPd5 [In German].

5. Humor // Encyclopedia Britannica. 2019. P. 27. URL: https:// www.britannica.com/print/article/276309. [In English].

6. Philosophy of Humour // Stanford Encyclopedia of Philosophy. 2012. 23 p. URL: https: plato.stanford.edu/entries/humour/. [In English].

7. Raskin V. Semantic Mechanisms of Humor. Dordrecht: Reidel, 1984. P. 325-335. [In English].

8. Zeit. «Bester Komiker»: Felix Lobrecht erhält den deutschen Comedypreis. 2019. URL: https://bit.ly/3aqOTLB [In German].

9. 70. Geburtstag von Otto Waalkes: „Die Komik entwickelt sich von selbst». Deutschlandfunkkultur. 2018. URL: https://bit.ly/3syUYff [In German]. 